\title{
SCREENING STUDIES OF ANTIAMNESIC AND ANTIHYPOXIC ACTIVITIES FOR SOME NEW 7,8-DISUBSTITUTED THEOPHYLLINE
}

\section{@D. B. Korobko}

\author{
SHEI «Ternopil state medical university named afterl.Ya. Horbachevsky of MPH of Ukraine»
}

\begin{abstract}
SUMMARY. The results of the study antiamnesic and antihypoxic activity of some new 7,8-disubstituted theophylline have been developed. Antiamnesic activity of original derivatives of 1,3-dimethylxanthine studied on the model of retrograde (hypoxic injury) amnesia conservation reflex of passive avoidance conditioned response. As an experimental model for the study of antihypoxic activity was considered acute pathological process that occurs in animals in an enclosed space. Installed some patterns in the series «structure of matter - biological activity».

KEY WORDS: hypoxia, antioxidant properties, conventional passive avoidance reaction, 7,8-disubstituted theophylline, piracetam, pentoxifylline.
\end{abstract}

Introduction. Hypoxia - a pathological condition, in which tissues and organs not saturated with oxygen or oxygen enough, but it is not absorbed by the tissue. Hypoxic conditions occur under the influence of physical, chemical and biological factors worsen the course of cardiovascular, nervous system, gastrointestinal tract, the function of blood. The main pathogenetic link in oxygen starvation of tissues of any nature is mitochondrial dysfunction, abuse of power supply, lipid peroxidation, antioxidant protection, instability of membranes. Hypoxic conditions mayoccur in diseases of the cardiovascular system, disruption of the endocrine respiratory diseasesduring fetal development and childbirth, poisoning related to chemicals from collapses in mines, significant physical stress, with the rise in the highlands. Various forms of hypoxia, including ischemia, is a major cause of cerebral stroke and coronary heart disease. Nowadays, extreme, sports and military medicine is a topical search tools that increase resistance to adverse factors, including hypoxia [1]. Therefore, the development of highly efficient and low-toxic antihypoxants actual problem of modern medicine and pharmacology.

The aim was to study antiamnesic and antihypoxic activities for some new 7,8-disubstituted theophylline.

Materials and methods of research. Nootropic medicines are used for various forms of drug therapy in patients with neuropsychiatric disorders and long pharmacocorrection of emotional stress in healthy people that cause development of psychosomatic diseases [2]. For some of them improve memory (pyrrolidone derivatives) is the leading pharmacological effect, and for drugs with other chemical groups neuroprotective action - just one manifestation of activity. The dominant component of the mechanism of action of nootropic drugs is their antiamnesic effect, is the ability to prevent or mitigate the violation of learning and memory caused by different damaging factors. Given the results of a study of antioxidant characteristics of some synthesized compounds seemed appropriate to undertake a study of their possible antiamnesic action on laboratory on animals obtained from the vivarium of the Institute of Pharmacology and Toxicology Medical Science of Ukraine.

Pentoxifylline, a representative alkylxanthine, has a unique mechanism of action that allows it to increase in the body content of endogenous antihypoxants and simultaneously reduce the level prohypoxante - prostaglandin E2. The synthesized compounds we are of the alkylxanthine derivatives and, in addition, a number of these substances significantly affects the processes of free radical oxidation, they have been tested on a model that detects antihypoxic activity (normobaric hypoxia or hypoxia «enclosed» space) [3].

Results and discussion. In pharmacological trials, which is a continuation of experimental studies [4], we have used a similar substances of new synthesized 7,8disubstituted theophylline.

Antiamnesic activity previously undescribed derivatives of 1,3-dimethylxanthine studied on the model of retrograde (hypoxic injury) amnesia conservation reflex conditioned reaction of passive avoidance (CRPA) [5]. The results of experimental studies are presented in table 1 and figures 1,2 .

According to the analysis of the data, modeling retrograde amnesia in laboratory animals in the control group showed the presence of cognitive deficits, which manifests itself in a significant reduction of latency CRPA relatively intact group of animals. Previous investigational compounds weakened infringement learning and memory. Antiamnesic action is best manifested in the use of substances 1, 4 and 7 . As main identified compound ethyl 2- (2-2-(1,3-dimethyl-2,6-dioxo-7-(3phenylalyl)-2,3,6,7-tetrahydro-1H-purine-8-yl)hydrazono)-2- $n$-tolylacetate: activity against comparison medicines piracetam - $464 \%$.

Research antihypoxic activity carried out on white mice weighing 18-20 g, obtained from the vivarium of the Institute of Pharmacology and Toxicology Medical Science of Ukraine. As an experimental model of acute considered pathological process that occurs in animals in «enclosed» space volume of $500 \mathrm{sm}^{3}$. 
Оеляди літератури, оригінальні дослідження, поеляд на проблему

Coefficient of antihypoxic protection determined by of experimental studies are presented in table 2 and the extension of time to first apneain animals. The results figures 3,4 .

Table 1. Effect of the substances obtained to preserve CRPA in rats $(n=5)$ in modeling retrograde amnesia $(M \pm m)$

\begin{tabular}{|c|c|c|c|}
\hline $\begin{array}{c}\text { Code } \\
\text { compound }\end{array}$ & Dose, $\mathrm{mg} / \mathrm{kg}$ & $\begin{array}{c}\text { The latent period of the event } \\
\text { the dark compartment, } \mathrm{s}\end{array}$ & $\begin{array}{c}\text { Preservation } \\
\text { memorable track, } \%\end{array}$ \\
\hline Intact & - & $3,27 \pm 1,6$ & - \\
\hline 1 & 10,0 & $6,2 \pm 0,8^{*}$ & 310,0 \\
\hline 2 & 10,0 & $2,66 \pm 0,11$ & 27,5 \\
\hline 3 & 10,0 & $2,55 \pm 0,14$ & 435,0 \\
\hline 4 & 10,0 & $10,7 \pm 0,9^{*}$ & 125,0 \\
\hline 5 & 10,0 & $4,50 \pm 0,12^{*}$ & 127,5 \\
\hline 6 & 10,0 & $4,54 \pm 0,11^{*}$ & 599,0 \\
\hline 7 & 50,0 & $13,98 \pm 0,14$ & - \\
\hline Control & - & $2,0 \pm 0,1$ & 135,0 \\
\hline Piracetam & 250,0 & $4,7 \pm 0,18^{*}$ & \\
\hline
\end{tabular}

Notes: $1 .{ }^{*}-p<0,05$ relative to the control; $2 .^{+}-p<0,05$ relative to piracetam.

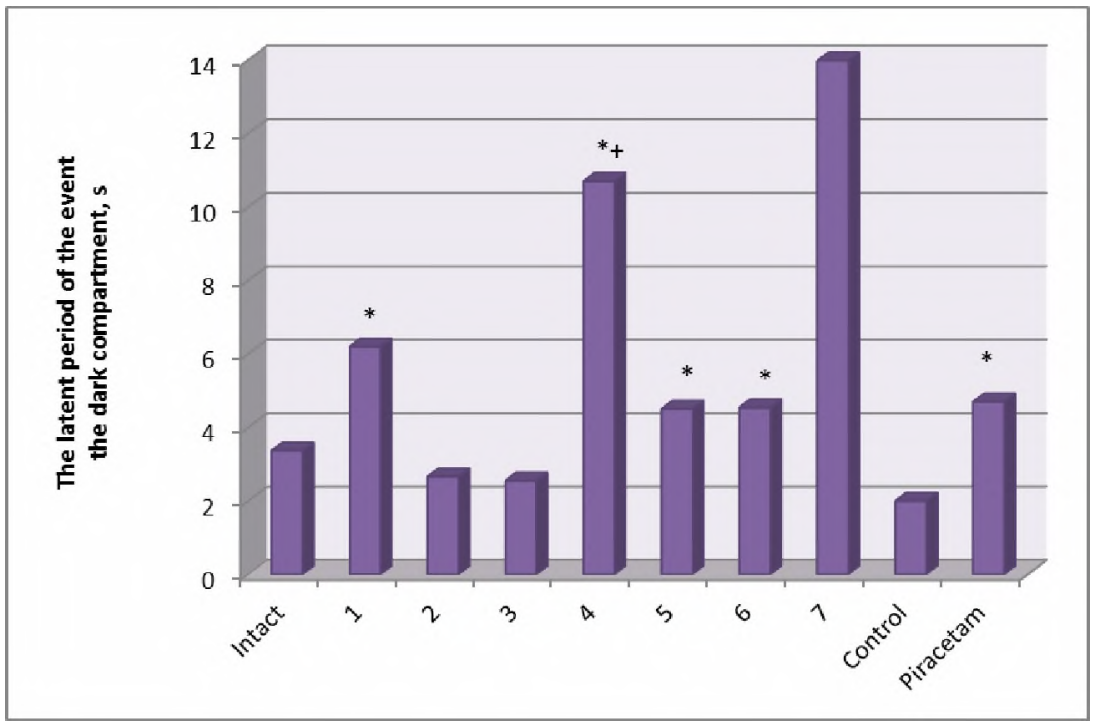

Figure 1. Effect of the obtained substances to preserve CRPA in rats in modeling retrograde amnesia (latent period of the event in the dark compartment).

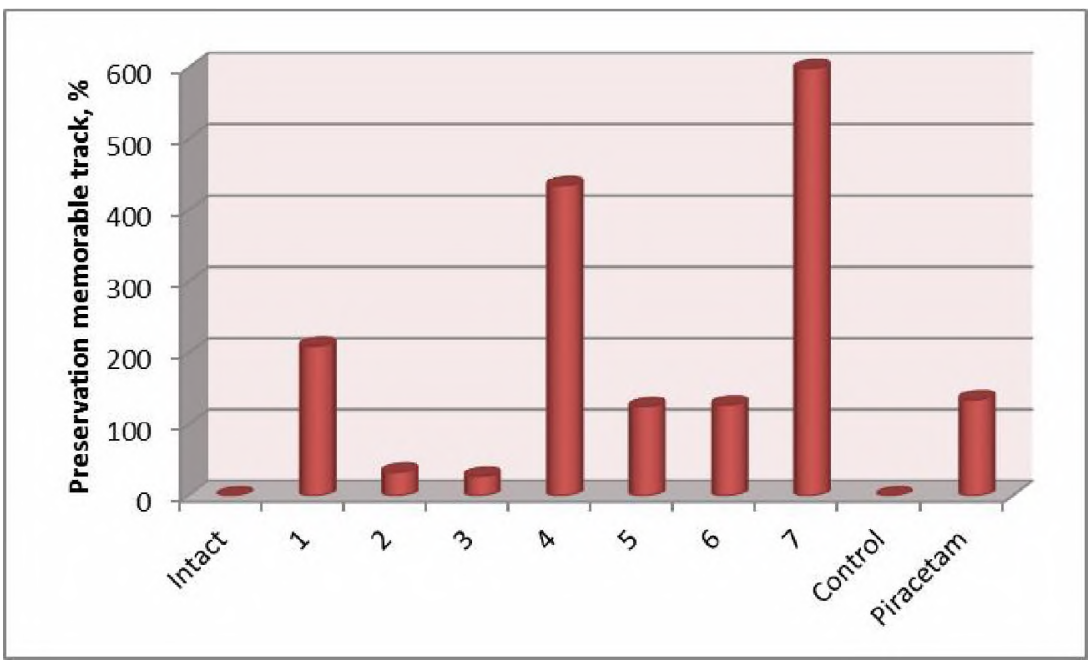

Figure 2. Effect of the obtained substances to preserve CRPA rats in modeling retrograde amnesia (preservation memorable track). 
Оеляди літератури, ориаінальні дослідження, поеляд на проблему

Table 2. Research of antihypoxic action synthesized compounds in terms of modeling normobaric hypoxia $(n=5)$

\begin{tabular}{|c|c|c|c|}
\hline $\begin{array}{c}\text { Code } \\
\text { compound }\end{array}$ & Dose, $\mathrm{mg} / \mathrm{kg}$ & $\begin{array}{c}\text { Life expectancy, } \\
\text { minutes }\end{array}$ & Antihypoxic action, \% \\
\hline 1 & 10,0 & $11,6 \pm 0,03^{*}$ & 260,0 \\
\hline 2 & 10,0 & $5,17 \pm 0,16^{*}$ & 60,0 \\
\hline 3 & 10,0 & $4,00 \pm 0,82$ & 24,2 \\
\hline 4 & 10,0 & $11,62 \pm 0,03 *^{+}$ & 260,0 \\
\hline 5 & 10,0 & $4,00 \pm 0,05$ & 24,2 \\
\hline 6 & 10,0 & $6,00 \pm 0,11$ & 46,3 \\
\hline 7 & 50,0 & $17,62 \pm 0,14$ & - \\
\hline Control & - & $3,22 \pm 0,12$ & 60,0 \\
\hline Piracetam & 250,0 & $5,17 \pm 0,11^{*}$ & 2 \\
\hline
\end{tabular}

Notes: $1 . *-p<0,05$ relative to the control; $2 .^{+}-p<0,05$ relative to piracetam.

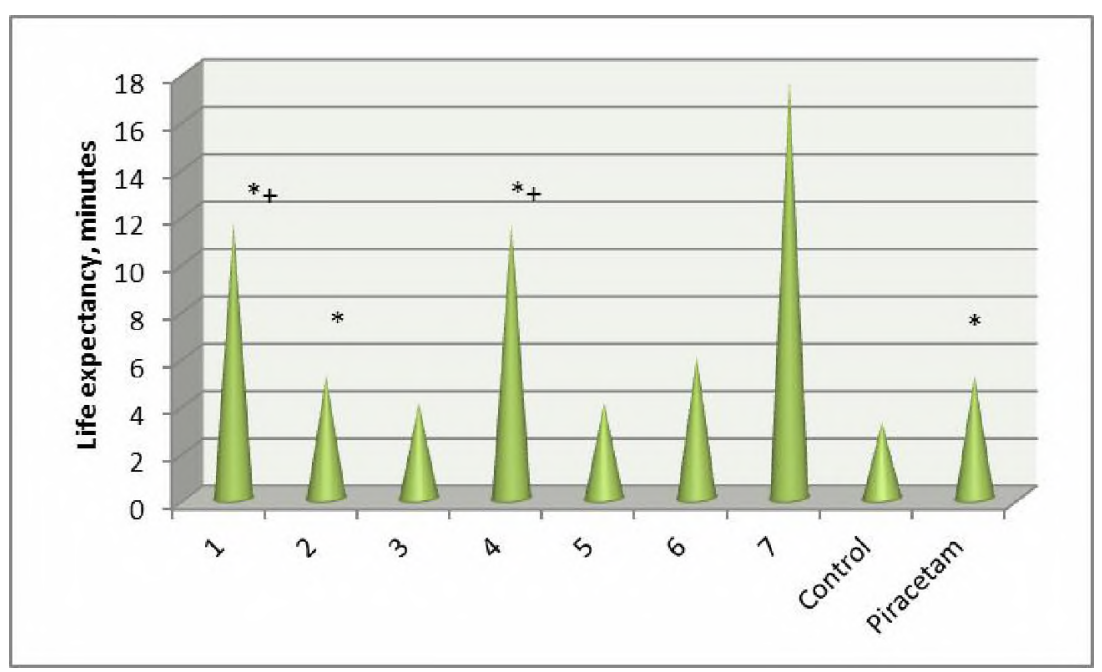

Figure 3. Research of antihypoxic action synthesized compounds in terms of modeling normobaric hypoxia on life expectancy.

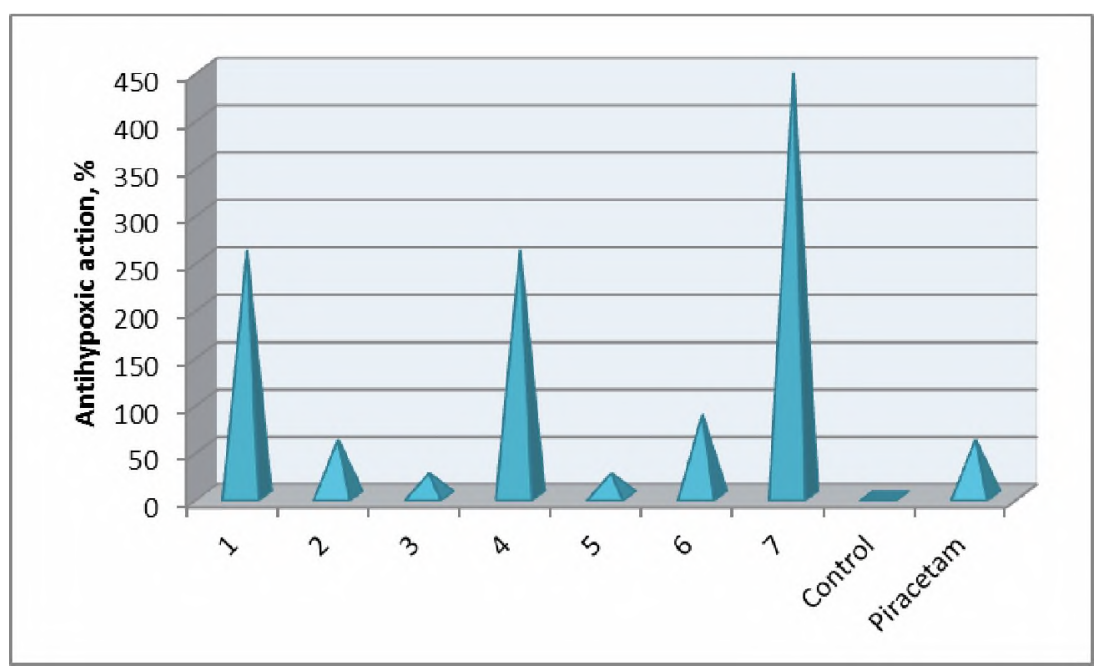

Figure 4. Antihypoxic action of the synthesized compounds in terms of modeling normobaric hypoxia.

Thus, the analysis of the primary pharmacological screening showed a definite need for further, more in-depth studies of the synthesized 7,8-disubstituted theophylline. Thus, among the 7 tested substances only 2 per performance inferior to the reference drug. At the same high level in terms of normobaric hypoxia are already above compounds 1 and 4. However, the life expectancy of laboratory animals (17.62 min against control $3.22 \mathrm{~min}$ ) most affects substance 7 . Its activity was $547.2 \%$ compared to controlor 7.45 times higher relative piracetam.

Conclusions. 1. Most of the tested compounds showed pronounced antiamnesic and antihypoxic activities in the respective models. 
Оеляди літератури, ориаінальні дослідження, поеляд на проблему

2. Identified «main compound» (substance 7), which is used for its efficiency models were substantially more reference drugs.

3. Installed some patterns among «the structure of matter - biological activity".
Prospects for future research will be used as the chemical modification of compounds leader to improve its pharmaco-technological characteristics, and the creation of new combinatorial libraries 7,8-disubstituted theophylline, which contain a halogen arylalkyl fragment.

\title{
REFERENCES
}

1.Пругло Є. С. Антигіпоксична активність алкілпохідних 5-(адамантан-1-іл)-4-R-1,2,4-тріазол-3-тіону / Є. С. Пругло, В. М. Одинцова, А. А. Сафанов // Запорізький медичний журнал. - 2013. - № 3 (78). - С. 59-64.

2. Gabryel B. Piracetam and vinpocetine exert cytoprotective activity and prevent apoptosis of astrocytes in vitro in hypoxia and reoxygenation / B. Gabryel, M. Adamek, A. Pudelko // Neurotoxicology. - 2002. - № 23. - P. 19-31.

3. Пошук і експериментальне вивчення потенційних протигіпоксичних засобів : метод. реком. / [В. Д. Лук'ян-

чук, Л. В. Савченкова, О. Д. Немятих та ін.]. - Ки в: ДФЦ МОЗ Укра ни, 2002. $-26 \mathrm{c.}$

4. Коробко Д. Б. Вивчення антирадикально та мітопротективно ді ряду оригінальних 7-арилалкіл-8-гідразинопохідних 1,3-диметилксантину / Д. Б. Коробко // Здобутки клінічно і експериментально медицини. 2014. - № 1. - С. 51-55.

5. Експериментальне вивчення ноотропно активності фармакологічних сполук : метод. реком. / [М. Я. Головенко]. - Ки в, 2002. - 27 с.

\section{СКРИНІНГОВІ ДОСЛІДЖЕННЯ АНТИАМНЕСТИЧНО ТА АНТИГІПОКСИЧНО АКТИВНОСТІ ДЛЯ ДЕЯКИХ НОВИХ 7,8-ДИЗАМІЩЕНИХ ТЕОФІЛІНУ}

СД. Б. Коробко

\author{
ДВНЗ «Тернопільський державний медичний університетімені І. Я. Горбачевського МОЗ України»
}

РЕЗЮМЕ. У статті представлені результати вивчення антиамнестично та антигіпоксично активностей ряду нових 7,8-дизаміщених теофіліну. Антиамнестична активність оригінальних похідних 1,3-диметилксантину вивчалась на моделі ретроградно (гіпоксична травма) амнезі по збереженню рефлексу умовно реакці пасивного уникання. В якості експериментально моделі для вивчення антигіпоксично активності розглядався гострий патологічний процес, що розвивається у тварин в умовах замкнутого простору. Встановлені деякі закономірності в ряду «структура речовини - біологічна активність".

КЛЮЧОВІ СЛОВА: гіпоксія, антиоксидантні характеристики, умовна реакція пасивного уникання, 7,8-дизаміщені теофіліну, пірацетам, пентоксифілін. 